\title{
Functional status after major amputation in diabetic foot patients from a tertiary hospital
}

\author{
Ligia de Loiola Cisneros*, Aline da Conceição Arruda, Tulio Pinho Navarro \\ From 20th Brazilian Diabetes Society Congress \\ Porto Alegre, Brazil. 11-18 November 2015
}

\section{Background}

The impact of global diabetes burden is evidenced by the growing morbidity and mortality rates, and by permanent disabilities such as blindness, diabetic retinopathy, end-stage renal failure and lower extremity amputations.

\section{Objective}

The purpose of this study was to verify functional status of diabetic foot patients submitted to lower limb major amputation after the discharge of a university hospital, reference in vascular surgery. A cohort of 31 diabetic foot patients was identified from the electronic medical records. Data were retrospectively collected from each patients chart including age, gender, peripheral arterial disease, level of amputation and number of readmissions. Patients were contacted by phone. A questionnaire investigated the survival, functional and ambulatory status: prosthesis use, reason for non-implantation of prosthetics, other hospitalization and amputation, mobility, selfperformance of activities of daily living such as dressing and personal hygiene.

\section{Results}

The mean age of patients at the time of surgery was 65.23 yrs.(SD 11.86), 21 (67.7\%) patients were men. Peripheral arterial disease was present in 17 (54.8\%) of the sample. Below-the-knee amputation was performed in 16 (51.6\%), the mean time of amputation was 48.71 months (SD 21.29). From the total, 15 (48.4\%), were admitted only once and $6(19.4 \%)$ were readmitted one more time for diabetic foot problems and 4 (12.9\%) were submitted to other amputation, 12 (38.8\%) died. A total of 15 (48.4\%) subjects were fitted with prosthesis. Others diabetes complications were related by 5 (16.1\%)

* Correspondence: ligialoyola@gmail.com

Universidade Federal de Minas Gerais, Belo Horizonte, Brazil patients as the main reason for non-implantation of prosthetics. Twelve (38.8\%) patients were able to walk, $15(48.4 \%)$ were on wheelchair and $4(12.8 \%)$ rest on bed after the amputation. A reduction in self-performance of activities of daily living were reported by $11(35.5 \%)$ patients.

\section{Conclusion}

These findings exemplify the decrements in functioning for elderly diabetic foot patients after a major amputation.

Published: 11 November 2015

doi:10.1186/1758-5996-7-S1-A21

Cite this article as: de Loiola Cisneros et al:: Functional status after major amputation in diabetic foot patients from a tertiary hospital. Diabetology \& Metabolic Syndrome 2015 7(Suppl 1):A21.

\section{Submit your next manuscript to BioMed Central and take full advantage of: \\ - Convenient online submission \\ - Thorough peer review \\ - No space constraints or color figure charges \\ - Immediate publication on acceptance \\ - Inclusion in PubMed, CAS, Scopus and Google Scholar \\ - Research which is freely available for redistribution

